\title{
Financial Ratio Analysis in Launchpad Learning Labs Pvt Ltd
}

\author{
CS. Gowtham Chakravarthy, S.Praveen Kumar, J. Pavithra
}

\begin{abstract}
Budget summary examination is generally an investigation of the relationship among the different money related factors in a business as unveiled by single lot of articulations. It is a procedure of assessing the connection between segments portions of fiscal reports to getting better comprehension of an uncompromising stance's and execution. An endeavor to decide the noteworthy and importance of the fiscal reports information with the goal that conjecture might be made of things to come income capacity to pay intrigue and obligation developments ( both present and long haul) and gainfulness of a sound approach. [1],[3],[5]
\end{abstract}

Various technique or gadgets are utilized for the investigation the asset report and pay proclamations of Launchapad learning labs pvtltd for the period 5 years. This examination is finished by utilizing different monetary apparatuses, measurable instruments. The diagrams were utilized as needs be to help the examination the budget summaries are one of the vital reports utilized by the two chiefs and proprietors or potential proprietors. To assess the achievement or generally of the association. Research demonstrates that the yearly report is the key archive for the establishment financial specialists in thinking about corporate execution. [2 ],[ 4],[6]

In view of the examination owned with the budgetary expression of the launchpadlc from 2014-2018 the specialist like to presume that the liquidity proportion are not ideal and furthermore the net revenue is diminishing at a higher rate, which demonstrates expanding working costs of the organization executes the recommendation made alongside the investigation. The organization can improve its presentation in the coming year. [7],[ 9],[11]

\section{Keywords : Finance,Research,analysis}

\section{INTRODUCTION}

Budget report examination is to a great extent an investigation of the relationship among the different budgetary factors in a business as unveiled by single lot of articulations. It is a procedure of assessing the connection between segments portions of fiscal reports to getting better comprehension of an uncompromising stance's and execution. An endeavor to decide the noteworthy and

Revised Manuscript Received on July 22, 2019.

CS.Gowtham chakravarthy, Department of MBA, Bharath Institute of Higher Education and Research, Tamilnadu, India Email: chakravins@gmail.com

Dr.S.Praveen Kumar, Department of MBA, Bharath Institute of Higher Education and Research, Tamilnadu, India. Email: praveenkumar.mba@bharathuniv.ac.in

J.Pavithra, Department of MBA, Bharath Institute of Higher Education and Research, Tamilnadu, India. Email: pavithralect@yahoo.com significance of the budget reports information with the goal that conjecture might be made of things to come income capacity to pay intrigue and obligation developments ( both present and long haul ) and gainfulness of a sound arrangement. [8],[10],[12]

Various strategy or gadgets are utilized for the examination the asset report and pay articulations of Launchapad learning labs pvt ltd for the period 5 years. This investigation is finished by utilizing different money related instruments, measurable devices. The diagrams were utilized as needs be to help the examination the fiscal reports are one of the urgent records utilized by the two chiefs and proprietors or potential proprietors. To assess the achievement or generally of the association. Research demonstrates that the yearly report is the key archive for the establishment financial specialists in thinking about corporate execution. 13], [15] ,[ 17]

The fundamental fiscal summaries contain and the principle bookkeeping suspicions that are inalienable in their development. We at that point direct over concentration toward examining a lot of distributed records with the end goal of increasing some knowledge into the presentation of the organization. A portion of the issues engaged with the utilization of monetary proportions for evaluating execution will likewise he tended to. [14],[ 16], [18]

The principle errand of money related bookkeeping is to impart monetary data. It is tied in with distinguishing, estimating, recording and announcing of a venture. Thus a focal worry in the arrangement of helpful dependable data identifies with the strategies for estimating worth and benefits. As you would expect there are various manners by which these estimations could be made. As our emphasis is on the utilization which can be made a monetary data. It isn't expectation to go into protracted specialized obligations on bookkeeping matters in perceiving the money related data is an imperative piece of data for the administration basic leadership. It is similarly essential to perceive that genuine investigation will fundamentally look. [19],[21],[23]

\section{RESEARCH METHODOLOGY}

\section{A. Significance of the study}

Proportion examination is a significant and age old method of money related investigation. The information given in fiscal reports are dump and can't impart anything. Proportion are relative type of money related information and extremely

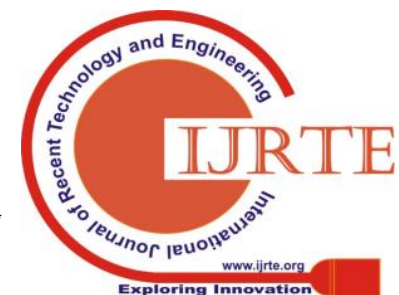


helpful; strategy to check upon the effectiveness of a firm. A few proportions show the pattern or advancement or ruin of the firm. [20],[22], [24]

\section{B. RESEARCH MEANING}

Research is regular speech alludes to a quest for information. One can likewise characterize as a logical and orderly, scan for certain data on a particular subject in actuality research is an alt of logical examination. A few people think about research as developments from known to obscure. [25],[27],[29]

- As indicated by Clifford woody research contains characterizing and rethinking issues, planning speculation, proposed arrangements, gathering, sorting out and finally cautiously testing the ends to decide if they fit the defining theory.

- To know the acquiring limit.

- To know the productivity of the executives.

- To know the monetary quality of the business.

- To know the dissolvability.

- To make near examination with different firms.

The study has extraordinary hugeness and gives advantages to different gatherings whom straightforwardly or in a roundabout way collaborate with the organization

\section{Objectives of the study}

There are two objectives are three.

i) Primary objective

ii) Secondary objective

\section{Primary Objective}

To analyse the Financial ratio analysis of Launchpad learning labs pvt ltd, Chennai belongs to 2014-2018

\section{E. Secondary Objective}

To study the efficiency the firm through ratio analysis.

$>$ To study the financial position of the company.

To evaluate the working capital performance of the company.

To study the liquidity position of the company.

To forecast the financial growth of the company.

\section{RESEARCH DESIGN}

Descriptive research design method has been used in this study. Where the researcher can report what has happened without having control over the variables. [31],[33],[32]

\section{A. NATURE OF DATA}

The nature of data used for the study is secondary data. Because the data is collected from the balance sheet for the analysis part.

Source of the data:

\section{Secondary data:}

The data related to profitability position, financial position and other operational results were collected from the published annual reports of five years of the "Launchpad 1lc pvt Ltd" (2014-2018)

\section{B. METHOD OF DATA COLLECTION}

The data required for the period of 2014-2018 have been obtained from the company records of financial statements The study is entirely based on the secondary data through the company records. Secondary data has been in this study the published financial reports of Launchpad learning labs private limited, directors reports and annual report has been the main source of secondary data. [26],[28],[30]

\section{PERIOD OF THE STUDY}

The period of the study is the five financial year starting from 2014-2018.

\section{TOOLS FOR ANALYSIS}

The data so collected have been analyzed with he help of following accounting tools and statistical tools.
1. Ratio analysis
2. Comparative balance sheet
3. Common size statement

\section{DATA ANALYSIS AN INTERPRETATION}

\section{CURRENT RATIO}

Table :1 Current Ratio

\begin{tabular}{|l|l|l|l|}
\hline Year & Current assets & Current liabilities & Ratio \\
\hline $2013-2014$ & 40469 & 35837 & 1.13 \\
\hline $2014-2015$ & 62614 & 38959 & 1.61 \\
\hline $2015-2016$ & 75143 & 36537 & 2.06 \\
\hline $2016-2017$ & 70059 & 47901 & 1.46 \\
\hline $2017-2018$ & 63466 & 103067 & 0.62 \\
\hline
\end{tabular}

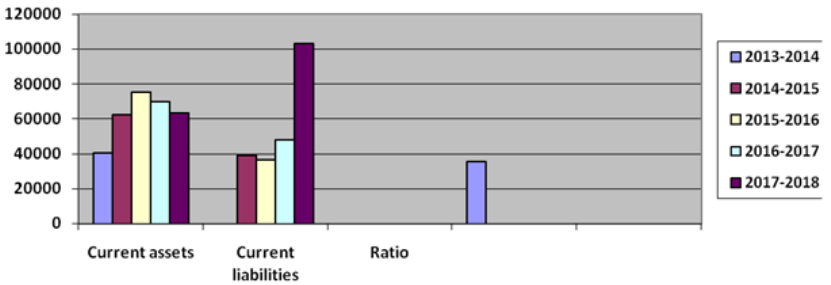

Fig:1 


\section{INTERPRETATION}

From the table it is observed that, in the current ratio is increasing gradually from 1.12 to 0.62 from 2014 to 2018 it is an undesirable position. The current ratio of the company is less than the ideal ratio. The ratio should be maintained compulsorily for every year increasing in current ratio.

\section{QUICK RATIO}

Table:2 Quick Ratio

\begin{tabular}{|l|l|l|l|}
\hline Year & Quick assets & Current liabilities & Ratio \\
\hline $2013-2014$ & 7928 & 35837 & 0.22 \\
\hline $2014-2015$ & 13962 & 38959 & 0.36 \\
\hline $2015-2016$ & 23852 & 36537 & 0.65 \\
\hline $2016-2017$ & 41153 & 47901 & 0.86 \\
\hline $2017-2018$ & 48752 & 103067 & 0.47 \\
\hline
\end{tabular}

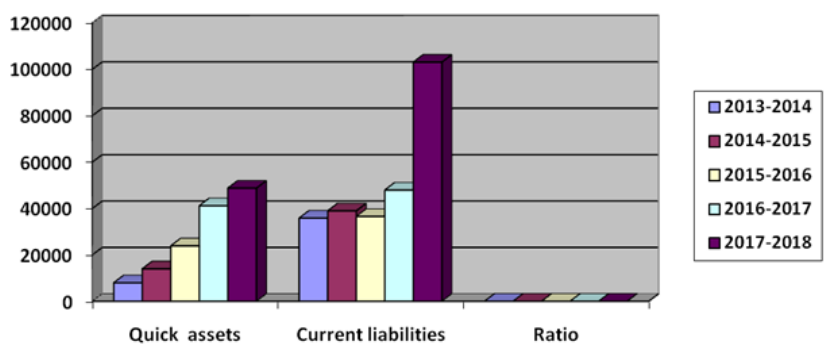

Fig:2

\section{INTERPRETATION}

From the table it is observed that, the quick ratio in increasing gradually from 0.22 to 0.47 during period. It is an undesirable position; the minimum ratio should be 1:1 This ratio should be maintained compulsorily for every year; otherwise the company has faced the company has faced the liquidity in future.

\section{DEBT EQUITY RATIO}

\section{Table:3 Debt- Equity Ratio}

\begin{tabular}{|l|l|l|l|}
\hline Year & Outsiders fund & Shareholders fund & Ratio \\
\hline $2013-2014$ & 30491 & 39249 & 0.78 \\
\hline $2014-2015$ & 23136 & 35515 & 0.65 \\
\hline $2015-2016$ & 43619 & 86372 & 0.51 \\
\hline $2016-2016$ & 99703 & 92571 & 1.08 \\
\hline $2017-2018$ & 127540 & 108041 & 1.18 \\
\hline
\end{tabular}

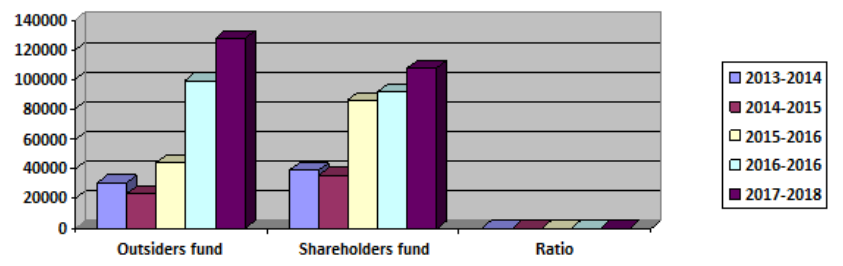

Fig:3

\section{INTERPRETATION}

The study period the ratio is around 3 . It means the long debt of the company is 3 times greater than shareholder funds. So the company has to improve the equity debt ratio, so that long term solvency position of company can be improved.

\section{PROPRIETARY RATIO}

Table :4 Proprietary Ratio

\begin{tabular}{|l|l|l|l|}
\hline Year & Shareholders fund & Total assets & Ratio \\
\hline $2013-2014$ & 39249 & 125135 & 0.31 \\
\hline $2014-2015$ & 35515 & 174929 & 0.20 \\
\hline $2015-2016$ & 86372 & 199527 & 0.43 \\
\hline $2016-2017$ & 92571 & 230849 & 0.40 \\
\hline $2017-2018$ & 108041 & 254229 & 0.42 \\
\hline
\end{tabular}

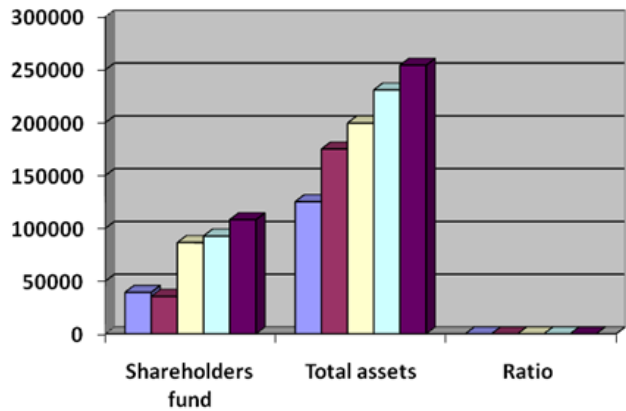

Fig:4

\section{INTERPRETATION}

During the study period, ratio increased 0.31 to 0.42 even though the ratio is increasing in the study period, it is below the 3 . A ratio below 3 is alarming for the creditors since they have to lose heavily in events of company's liquidation as it indicate more of creditors fund and less of shareholder funds in the total assets of the firm.

\section{NET PROFIT RATIO}

\section{Table :5 Net profit Ratio}

\begin{tabular}{|l|l|l|l|}
\hline Year & Net profit & Sales & Ratio \\
\hline $2013-2014$ & 24684 & 110720 & 22.29 \\
\hline $2014-2015$ & 914 & 132148 & 0.69 \\
\hline $2015-2016$ & 12722 & 151862 & 8.37 \\
\hline $2016-2017$ & 9507 & 171940 & 5.53 \\
\hline $2017-2018$ & 25120 & 205990 & 12.20 \\
\hline
\end{tabular}

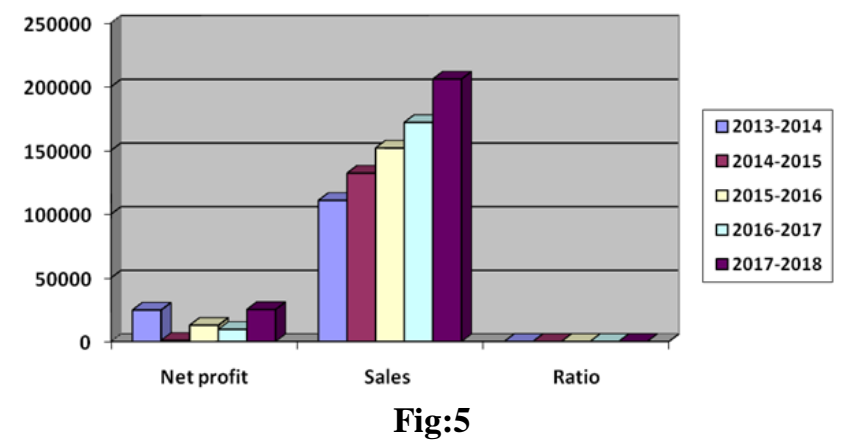

\section{INTERPRETATION}

The figure reveals the operation efficiency of 'LAUNCHPAD LEARNING LABS PVT LTD' in the year 2013-2014 to 2017-2018 because the Net profit Ratio shows decreasing trend (2013-14 (22.29) to $2017-18$ (12.20). 
FIXED ASSETS TURNOVER RATIO

Table :6 Fixed Assets Turnover Ratio

\begin{tabular}{|l|l|l|l|}
\hline Year & Sales & Fixed assets & Ratio \\
\hline $2013-2014$ & 110720 & 84608 & 1.31 \\
\hline $2014-2015$ & 132148 & 112257 & 1.78 \\
\hline $2015-2016$ & 151862 & 124326 & 1.22 \\
\hline $2016-2017$ & 171940 & 160732 & 1.07 \\
\hline $2017-2018$ & 205990 & 189668 & 1.09 \\
\hline
\end{tabular}

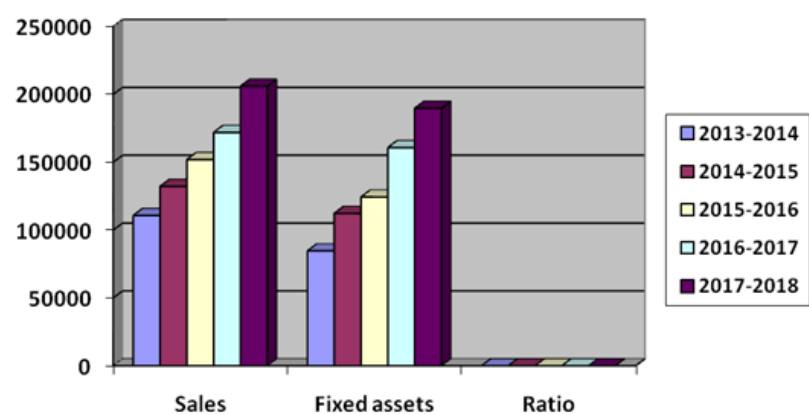

Fig:6

INTERFERANCE

This figure shows decreasing trend of fixed assets turnover ratio in the year 2013-14 (1.31) to 2017-18 (1.09).

\section{DEBTOR'S TURNOVER RATIO}

Table:7 Debtor's Turnover Ratio

\begin{tabular}{|l|l|l|l|}
\hline Year & Sales & Sundry debtor & Ratio \\
\hline $2013-2014$ & 110720 & 1487 & 74.46 \\
\hline $2014-2015$ & 132148 & 3870 & 34.15 \\
\hline $2015-2016$ & 151862 & 7251 & 20.94 \\
\hline $2016-2017$ & 171940 & 10657 & 16.13 \\
\hline $2017-2018$ & 205990 & 17391 & 11.85 \\
\hline
\end{tabular}

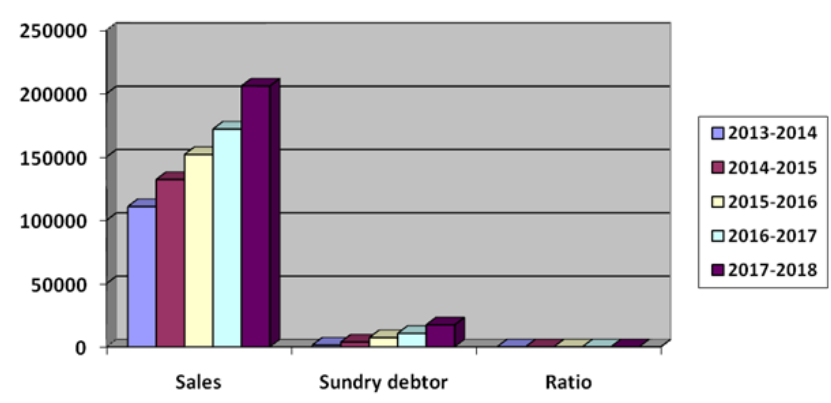

Fig:7

\section{INTERFERANCE}

In this figure shows debtors turnover ratio is decreased in each years. This indicates high liquidity of the debtors and quick convertibility of debtors into cash. figure shows Debtors turnover ratio in the year 2013-14 (74.46) to 2017-18 (11.85).

\section{RETURN ON TOTAL ASSTS}

Table:8 Return on Total assets Ratio

\begin{tabular}{|l|l|l|l|}
\hline Year & Net profit & Total sales & Ratio \\
\hline $2013-2014$ & 24684 & 110720 & 2.29 \\
\hline $2014-2015$ & 914 & 132148 & 0.69 \\
\hline $2015-2016$ & 12722 & 151862 & 8.38 \\
\hline $2016-2017$ & 9507 & 171940 & 5.53 \\
\hline $2017-2018$ & 25120 & 205990 & 12.20 \\
\hline
\end{tabular}

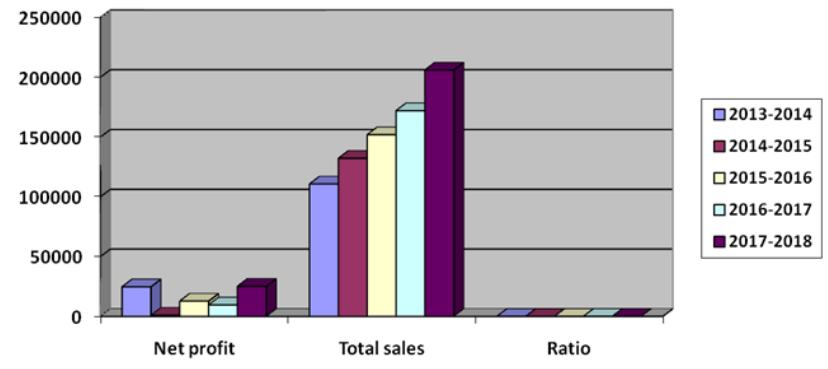

Fig:8

\section{INTERPRETATION}

This figure shows increasing trend of Return On Total Assets in the year 2013-14 (2.29) to 2017-18 (12.20). COMMON-SIZE BALANCE SHEET FOR THE YEAR 2013-14

Table :9Common size statement(2013-2014)

\begin{tabular}{|l|l|l|l|l|}
\hline \multirow{2}{*}{ PARTICULARS } & \multicolumn{2}{|l|}{$\mathbf{2 0 1 3}$} & $\mathbf{2 0 1 4}$ \\
\cline { 2 - 5 } & AMOINT & $\mathbf{\%}$ & AMOINT & $\mathbf{\%}$ \\
\hline CURRENT ASSETS & 21789 & 29.37 & 40469 & 32.34 \\
\hline FIXED ASSET & 52344 & 70.55 & 84608 & 67.61 \\
\hline INVESTMENT & 58 & 0.08 & 58 & 0.05 \\
\hline TOTAL ASSET & 74191 & $\mathbf{1 0 0}$ & $\mathbf{1 2 5 1 3 5}$ & $\mathbf{1 0 0}$ \\
\hline CURRENT LIABILITY & 17296 & 23.31 & 35837 & 28.64 \\
\hline SHARE CAPITAL & 2950 & 3.98 & 2950 & 2.36 \\
\hline RESERVES\&SURPLUS & 23374 & 31.51 & 36299 & 29.01 \\
\hline SECURED LOANS & 903 & 1.22 & 3761 & 3.01 \\
\hline UNSECURED LOANS & 22233 & 29.97 & 39858 & 31.85 \\
\hline DEFERRED TAX & 7435 & 10.02 & 6430 & 5.14 \\
\hline TOTAL LIABLITES & 74191 & $\mathbf{1 0 0}$ & $\mathbf{1 2 5 1 3 5}$ & $\mathbf{1 0 0}$ \\
\hline
\end{tabular}

\section{INTERPRETATION}

The fixed asset decreases to $67.61 \%$ and there is no change in share capital will affect the working capital of the company.

The current asset increases to $32.34 \%$ and the current liabilities increases to $28.64 \%$ it reveals that the company cannot make more profit.

From the above analysis the financial position of the company is good because the percentage of current liabilities is lower than the current assets.

COMMON-SIZE BALANCE SHEET FOR THE YEAR 2014-15

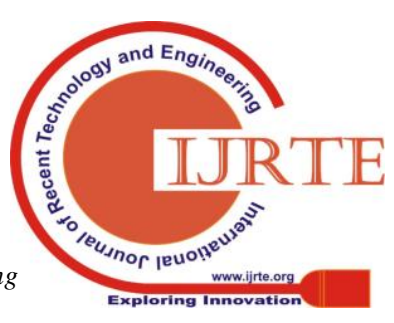


Table :10 Common size statement(2014-2015)

\begin{tabular}{|c|c|c|c|c|}
\hline \multirow[b]{2}{*}{ PARTICULARS } & \multicolumn{2}{|l|}{2014} & \multicolumn{2}{|l|}{2015} \\
\hline & AMOUNT & $\%$ & AMOUNT & $\%$ \\
\hline CURRENT ASSETS & 40469 & 32.34 & 62614 & 35.79 \\
\hline FIXED ASSET & 84608 & 67.61 & 112257 & 64.18 \\
\hline INVESTMENT & 58 & 0.05 & 58 & 0.03 \\
\hline TOTAL ASSETS & 125135 & 100 & 174929 & 100 \\
\hline CURRENT LIABILITY & 35837 & 28.64 & 38959 & 22.27 \\
\hline SHARE CAPITAL & 2950 & 2.36 & 2950 & 1.69 \\
\hline RESERVES\&SURPLUS & 36299 & 29.01 & 32565 & 18.62 \\
\hline SECURED LOANS & 3761 & 3.01 & 28200 & 16.12 \\
\hline UNSECURED LOANS & 39858 & 31.85 & 71503 & 40.88 \\
\hline DEFERRED TAX & 6430 & 5.14 & 752 & 0.43 \\
\hline TOTAL LIABILITES & 125135 & 100 & 174929 & 100 \\
\hline
\end{tabular}

\section{INTERPRETATION}

The fixed asset decreases to $64.18 \%$ and there is no change in share capital will affect the working capital of the company.

The current asset increases to $35.79 \%$ and the current liabilities decreases to $22.29 \%$ it reveals that the company cannot make more profit.

From the above analysis the financial position of the company is good because the percentage of current liabilities is lower than the current assets.

\section{COMMON-SIZE BALANCE SHEET FOR THE YEAR} 2015-16

Table :11 Common size statement (2015-2016)

\begin{tabular}{|c|c|c|c|c|}
\hline \multirow[t]{2}{*}{ PARTICULARS } & \multicolumn{2}{|l|}{2015} & \multicolumn{2}{|l|}{2016} \\
\hline & AMOUNT & $\%$ & AMOUNT & $\%$ \\
\hline CURRENT ASSETS & 62614 & 35.79 & 75143 & 37.66 \\
\hline FIXED ASSET & 112257 & 64.18 & 124326 & 62.31 \\
\hline INVESTMENT & 58 & 0.03 & 58 & 0.03 \\
\hline TOTAL ASSETS & 174929 & 100 & 199527 & 100 \\
\hline CURRENT LIABILITY & 38959 & 22.27 & 36537 & 18.31 \\
\hline SHARE CAPITAL & 2950 & 1.69 & 3820 & 1.92 \\
\hline RESERVES\&SURPLUS & 32565 & 18.62 & 82552 & 41.37 \\
\hline SECURED LOANS & 28200 & 16.12 & 34389 & 17.24 \\
\hline UNSECURED LOANS & 71503 & 40.88 & 41498 & 20.79 \\
\hline DEFERRED TAX & 752 & 0.43 & 731 & 0.37 \\
\hline TOTAL LIABIITES & 174929 & 100 & 199527 & 100 \\
\hline
\end{tabular}

\section{INTERPRETATION}

The fixed asset decreases to $62.34 \%$ and there is no change in share capital will affect the working capital of the company.

The current asset increases to $37.64 \%$ and the current liabilities decreases to $18.31 \%$ it revels that the company cannot make more profit.

From the above analysis the financial position of the company is good because the percentage of current liabilities is lower than the current assets.
COMMON-SIZE BALANCE SHEET FOR THE YEAR 2016-17

Table :12 Common size statement (2016-2017)

\begin{tabular}{|l|l|l|l|l|}
\hline \multirow{2}{*}{\multicolumn{1}{|c|}{ PARTICULARS }} & \multicolumn{2}{c|}{$\mathbf{2 0 1 6}$} & \multicolumn{2}{c|}{$\mathbf{2 0 1 7}$} \\
\cline { 2 - 5 } & \multicolumn{1}{|c|}{ AMOUNT } & \multicolumn{1}{c|}{$\%$} & \multicolumn{1}{c|}{ AMOUNT } & \multicolumn{1}{c|}{$\%$} \\
\hline CURRENT ASSETS & 75143 & 37.66 & 70059 & 30.35 \\
\hline FIXED ASSET & 124326 & 62.31 & 160732 & 69.63 \\
\hline INVESTMENT & 58 & 0.03 & 58 & 0.02 \\
\hline TOTAL ASSETS & 199527 & $\mathbf{1 0 0}$ & $\mathbf{2 3 0 8 4 9}$ & $\mathbf{1 0 0}$ \\
\hline CURRENT LIABILITY & 36537 & 18.31 & 47901 & 20.75 \\
\hline SHARE CAPITAL & 3820 & 1.92 & 3820 & 1.66 \\
\hline RESERVES\&SURPLUS & 82552 & 41.37 & 88751 & 38.45 \\
\hline SECURED LOANS & 34389 & 17.24 & 40628 & 17.59 \\
\hline UNSECURED LOANS & 41498 & 20.79 & 48978 & 21.22 \\
\hline DEFERRED TAX & 731 & 0.37 & 771 & 0.33 \\
\hline TOTAL LIABILITES & $\mathbf{1 9 9 5 2 7}$ & $\mathbf{1 0 0}$ & $\mathbf{2 3 0 8 4 9}$ & $\mathbf{1 0 0}$ \\
\hline
\end{tabular}

\section{INTERPRETATION}

The fixed asset increases to $69.63 \%$ and there is no change in share capital will affect the working capital of the company.

The current asset decreases to $30.35 \%$ and the current liabilities increases to $20.75 \%$ it reveals that the company cannot make more profit.

From the above analysis the financial position of the company is good because the percentage of current liabilities is lower than the current assets.

\section{V.RESULTS}

- The current ratio is decreasing from 1.13 to 0.74 during the study period.

- The quick ratio is increasing from gradually 0.22 to 0.47 during the study period.

- From the study that the equity ratio is high comparable over all the years. This implies that the debt equity ratio was satisfactory

- The company proprietary ratio shows increasing trend comparing to previous years.

- Net profit ratios also show increasing trend comparing other years because of quality of the product and price of the product

- The fixed asset ratio of the company is decreasing from 1.31 to 1.09 during the study period.

- Debtor's turnover ratio indicates is low, which is considered to be dissatisfactory or debtor's management is inefficient.

- Return on total assets ratio is increasing trend of the firm

- The common size statement is year to year comparing to increasing each every year during the study period.

\section{DISCUSSION}

> The company have to take steps to improve the management of working capital to meet its short term obligations. 
$>$ The company have to improve the management of accounts receivable by giving incentive for early settlement.

$>$ The owner's contribution should utilized properly in relation with the long-term assets.

$>$ The miscellaneous expenditure has gone up significantly over the years, which the management should consider seriously and take necessary actions to avoid them in the future.

$>$ The company have to take care of better and efficient utilization of assets for improving the efficiency.

\section{CONCLUSION}

Based on the analysis made with the financial statement of the launchpad llc from 2014-2018 the researcher like to conclude that the liquidity ratio are not favorable and also the net profit margin is decreasing at a higher rate, which indicates increasing operating expenses of the company implements the suggestion made along with the analysis. The company can improve its performance in the coming year.

\section{REFERENCES}

1. G BharthVajan R., Ramachandran S.,Psychographic dimensions of training,2016,International Journal of Pharmacy and Technology,V-8,I-4,P-23727-23729.

2. Balakrishnan P., Bharthvajan R.,A study on human resource planning in hospitals in Chennai City,2014,International Journal of Applied Engineering Research,V-9,I-22,P-7503-7507.

3. Priyadarsini P., Bharthvajan R.,Role of emotional intelligence training programme in reducing the stress of the nurses,2014,International Journal of Applied Engineering Research,V-9,I-22,P-7411-7421

4. Kerinab Beenu G., Bharthvajan R.,Empirical analysis on the cosmetic buying behavior of young women in South India,2014,International Journal of Applied Engineering Research,V-9,I-22,P-7361-7366.

5. Balakrishnan P., Bharthvajan R.,Whistling in the wind,2014,International Journal of Applied Engineering Research,V-9,I-22,P-7586-7593

6. Krishnan B., Peter M.,Health hazards of Indian Bpo employee-an alarming issue,2014,International Journal of Applied Engineering Research,V-9,I-22,P-7336-7341

7. Kerinab Beenu G.H., Peter M.,Role of insurance in economic development,2014,International Journal of Applied Engineering Research,V-9,I-22,P-7532-7539

8. Balakrishnan P., Peter M., Priyadarsini P.,Efficiency of safety measures for wellbeing of employees in manufacturing industry,2014,International Journal of Applied Engineering Research,V-9,I-22,P-7376-7382

9. Anbarasi M., Praveen Kumar S.,Online sales promotions of herbal products and its effectiveness towards tanisha.com,2019,Indian Journal of Public Health Research and Development,V-10,I-1,P-195-200

10. Anbarasi M., Praveen Kumar S.,Various online marketing and promotions strategies to improve the validation towards the organic products in the pharmaceutical sectors,2019,Indian Journal of Public Health Research and Development,V-10,I-1,P-263-269

11. Loganathan R., Praveen Kumar S.,Grievance handling a key factor for solving issues of employees in an organization,2014,International Journal of Applied Engineering Research,V-9,I-22,P-7483-7491

12. Loganathan R., Praveen Kumar S.,Study on preference of private label brands in super and Hypermarkets,2014,International Journal of Applied Engineering Research, V-9,I-22,P-7327-7335

13. Smitha M., Praveen Kumar S.,Understanding stress and its managementamong the nurses in Chennai city,2014,International Journal of Applied Engineering Research,V-9,I-22,P-7560-7565

14. Kerinab Beenu G.H., Praveen Kumar S.,A study on the investment behavior of Chennai investors in mutual fund schemes,2014,International Journal of Applied Engineering Research,V-9,I-22,P-7520-7525

15. Loganathan R., Praveen Kumar S.,Retention strategies key for organizational productivity,2014,International Journal of Applied Engineering Research,V-9,I-22,P-7443-7447

16. Pavithra J., Ganesan M., Brindha G.,State wise analysis of microfinance sector in India,2016,International Journal of Pharmacy and Technology,V-8,I-4,P-23417-23432
17. Pavithra J., Ganesan M.,A comparative study on microfinance in India and abroad,2016,International Journal of Applied Business and Economic Research,V-14,I-8,P-5471-5476

18. Pavithra J., Ganesan M.,A study on awareness and impact of micro-financial schemes,2016,International Journal of Applied Business and Economic Research,V-14,I-8,P-5449-5460

19. Senthilmurugan P., Pavithra J.,Consumer preference towards organised retailing with reference to Big Bazaar,2014,International Journal of Applied Engineering Research,V-9,I-22,P-7469-7475

20. Senthilmurugan P., Pavithra J.,Implication of social media marketing in growing healthcare industry,2014,International Journal of Applied Engineering Research,V-9,I-22,P-7448-7456

21. Loganathan R., Pavithra J.,Consumer perception towards private label brand over other brands in super markets and hypermarkets,2014,International Journal of Applied Engineering Research,V-9,I-22,P-7355-7360

22. Kerinab Beenu G., Pavithra J.,Tradeâ€"off between liquidity and profitability in logistics industry,2014,International Journal of Applied Engineering Research,V-9,I-22,P-7398-7401

23. Kerinab Beenu G., Pavithra J.,A study on the prospective consumerâ€ ${ }^{\mathbf{T M}_{\mathrm{S}}}$ perception towards utility cars in Chennai city,2014,International Journal of Applied Engineering Research,V-9,I-22,P-7526-7531

24. Pavithra J., Dilli Babu P., Ambuli T.V.,A study on budgetary control at Maruti Service Masters, Chennai,2014,International Journal of Applied Business and Economic Research,V-12,I-2,P-151-161

25. Pavithra J., Dilli Babu P., Ambuli T.V.,A study on customer satisfaction of retro Garments Pvt Ltd, Chennai,2014,International Journal of Applied Business and Economic Research,V-12,I-2,P-381-391

26. Kerinab Beenu G.H., Pavithra J., Senthilmurugan P.,A study on the influence of promotional activities for TATA ARIA among consumers in Chennai,2014,International Journal of Applied Engineering Research,V-9,I-22,P-7572-7578

27. Vijayaragavan S.P.,An investigative expert that's general FBG sensors, International Journal of Mechanical Engineering and Technology,V-8,I-8,PP-1500-1505,Y-2017

28. Vijayaragavan S.P.,Equalization routing protocol for Wi-Fi sensor strategy,International Journal of Mechanical Engineering and Technology,V-8,I-8,PP-1662-1666,Y-2017

29. Karthik B., Kiran Kumar T.V.U., Vijayaragavan P., Bharath Kumaran E.,Design of a digital PLL using 0.35 1̂1/4m CMOS technology,Middle East Journal of Scientific Research,V-18,I-12,PP-1803-1806,Y-2013

30. Kanniga E., Selvaramarathnam K., Sundararajan M.,Kandigital bike operating system,Middle - East Journal of Scientific Research,V

31. Jasmin M., Vigneshwaran T., Beulah Hemalatha S.,Design of power aware on chip embedded memory based FSM encoding in FPGA,International Journal of Applied Engineering Research,V-10,I-2,PP-4487-4496,Y-2015

32. Jasmin M.,Optimization techniques for low power VLSI circuits,Middle East Journal of Scientific Research,V-20,I-9,PP-1082-1087,Y-2014

33. Jasmin M., Vigneswaran T.,Fuzzy controller for error control of on - Chip communication,2017 International Conference on Algorithms, Methodology, Models and Applications in Emerging Technologies, ICAMMAET 2017,V-2017-January,I-,PP-1-5,Y-2017

\section{AUTHORS PROFILE}

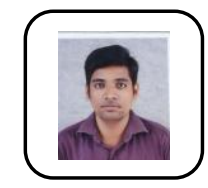

CS.Gowtham Chakravarthy Assistant Professor ,Department of MBA, Bharath Institute of Higher Education and Research, Tamilnadu, India

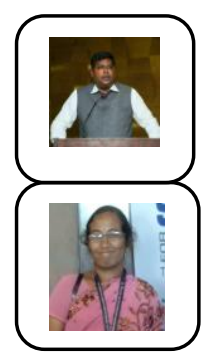

Dr.S.Praveen Kumar, Professor ,Department of MBA, Bharath Institute of Higher Education and Research, Tamilnadu, India

J.Pavithra Assistant Professor ,Department of MBA, Bharath Institute of Higher Education and Research, Tamilnadu, India 